\title{
August Tobler, the Swiss Pioneer of South Sumatra Geological Mapping, 1900-1912
}

\author{
J.T. (Han) van Gorsel ${ }^{\mathbf{1}}$ and Bernhard Gunzenhauser ${ }^{\mathbf{2}}$ \\ Retired ExxonMobil, Houston, Texas, USA \\ ${ }^{2}$ Retired Proseis $A G$, earlier with Shell Indonesia, Binningen, Switzerland
}

\section{INTRODUCTION AND SUMMARY}

Dr. August Tobler was a well-known Swiss geologist, who, as one of the very first petroleum field geologists in the Netherlands Indies, did more than ten years of geological mapping in the tiger-infested jungles of South Sumatra. He first worked for the Koninklijke/Royal Dutch and Moeara Enim oil companies in South Sumatra from 1900 to 1904 . This was followed by six more years of geological mapping in the Jambi basin, as the first non-Dutch geoscientist at the Dienst van het Mijnwezen (Geological Survey). His thoroughly documented monographs and geologic maps of his geological fieldwork in the Palembang and Jambi basins of South Sumatra, as well as the adjacent Barisan Mountains, set new standards for quality and detail.

Much of the personal information on Dr. Tobler is from papers by Kugler $(1930,1963)$, Oppenoorth (1930), Stehlin (1931) and Hottinger (2013). This paper is one of the chapters from a new book that is being prepared by the first author, entitled Pioneers and Milestones of Indonesian Geology ( 1820-1960).

\section{IN THE BEGINNING}

August Tobler was born in Basel on 29 April 1872, as the only child of a high school teacher. He studied geology and paleontology at the University of Basel from 1890 to 1895 and was one of the first students of the influential Prof. C. Schmidt. His studies included a few semesters at the LudwigMaximilians-Universität in Munich, under Prof. Karl von Zittel and A. Rothpletz. His doctorate in December 1895 was with a dissertation on the Jurassic of the SE Rhine Graben. After 1894 Tobler was Assistant of Prof. Schmidt in Basel, did research work in the Swiss Alps, and traveled to the USA and parts of Russia. He finished his Habilitation thesis in geology and paleontology and became a lecturer at the University of Basel in July 1899.

\section{SOUTH SUMATRA PETROLEUM GEOLOGICAL MAPPING}

Between early 1900 and 1912 Tobler worked under three separate geological mapping contracts in Sumatra and Java, as one of the first petroleum geologists in the country. For the first four years (early 1900 - mid-1904) he worked on contracts with two oil companies, and, after a break in Switzerland, for six years with the Dienst van den Mijnbouw (Geological Survey; mid-1906 - 1912).

\section{Koninklijke Olie/Royal Dutch, 1900-1903}

From early 1900 to early 1903 Tobler spent 3 years in South Sumatra, mapping oil-bearing anticlines in the Tertiary sediments of the South Sumatra basin for the Koninklijke Nederlandsche 

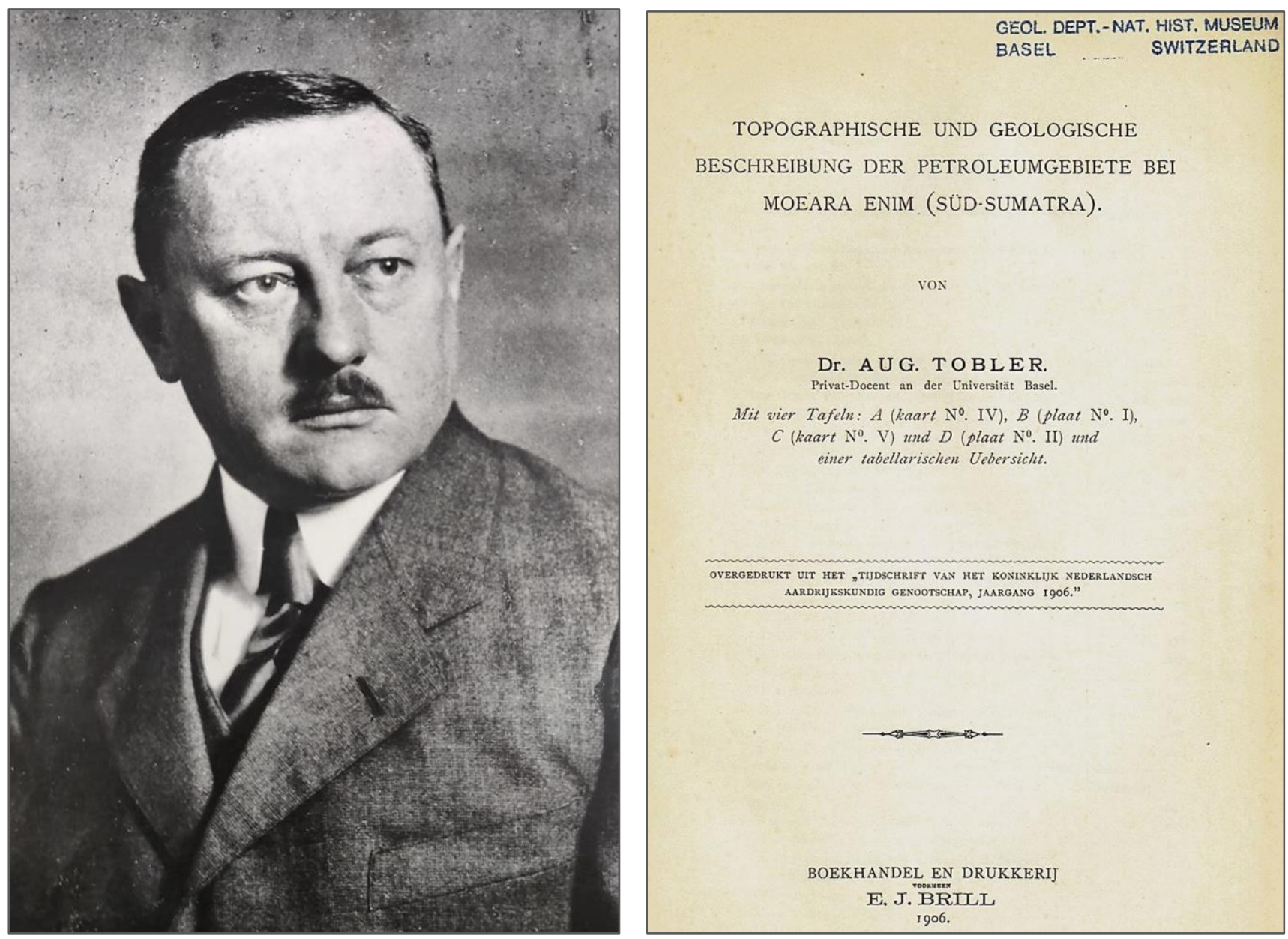

Figure 1: Portrait of August Tobler (from Stehlin, 1931). Figure 2: Cover of the first of Tobler's well-documented South Sumatra geologic mapping reports, on the petroleum regions near Muara Enim (Tobler, 1906).

Maatschappij tot Exploitatie van petroleumbronnen in Nederlandsch-Indie (= 'Royal Dutch', before its merger with Shell Transport). Unlike his later work in Sumatra, the work for Royal Dutch is unpublished, except for a summary in Tobler (1904).

\section{Muara Enim Petroleum Company, 1903- 1904}

After a short break in Switzerland in the summer of 1903 Tobler worked for 8 months on contract with the Petroleum-Maatschappij Moeara Enim, from September 1903 to May 1904, to produce detailed geological maps of their petroleumproducing anticlines in the Muara Enim area of South Sumatra (Figures 2, 3, 4, 5). This was a few years before Moeara Enim merged with the
Koninklijke. Unlike most oil company geological work during this era, and probably due to its visionary Director J.W. Ijzerman, Tobler was allowed to publish the results of this pioneering work in great detail (Tobler, 1906).

One result of Tobler's surveys in the Muara Enim area around 1904 was the discovery of local thermal alteration of the widespread Middle - Late Miocene lignitic coal beds. Adjacent to the young andesite intrusives the coal grade improved from lignitic to anthracite. In the late 1800s, Mijnwezen geologists like Everwijn and Verbeek did not consider the South Sumatra coal beds of any value, due to their low thermal grade. Tobler's discovery changed this perception and eventually led to the opening of the Bukit Asam coal mines. 


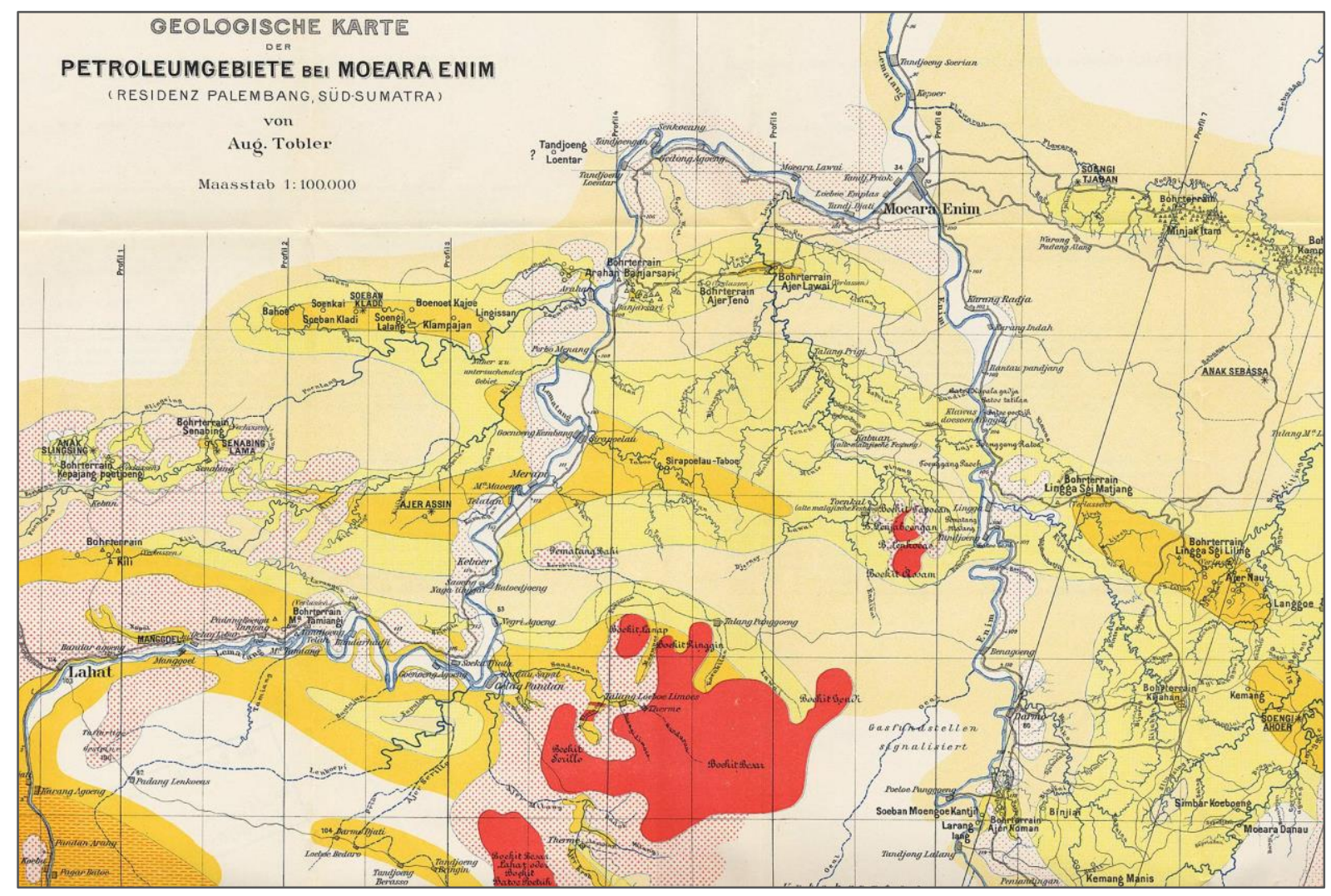

Figure 3: Part of Tobler (1906) surface geology map of the Muara Enim area, SW Palembang Basin, South Sumatra.

On his return from Sumatra in May 1904 Tobler met up with fellow Basel geologist A. Buxtorf in Singapore and from here they travelled to the oil fields of Burma and the Himalayan foothills of India. Back in Basel Tobler resumed his work on the geology of Central Switzerland, but also took several short consultant mapping jobs in Dalmatia, government contract employee. From November 1906 until July 1912 Tobler was Tijdelijk Geoloog (temporary geologist), in charge of the GeologicalMining survey project of the Jambi Residency, Sumatra (an area the size of Switzerland). The main goal of the work was to produce detailed geological maps of anticlinal structures in the Tertiary Jambi

Galicia and Italy (Stehlin, 1931).

Dienst van het Mijnwezen: Jambi basin/Barisan Mountains, 1906-1912

After a 2-year return to Switzerland in 1904-1906, Tobler was recruited by the Dienst van het Mijnwezen (Bureau of Mines/ Geological Survey) and moved back to the Netherlands Indies in September 1906, now as a

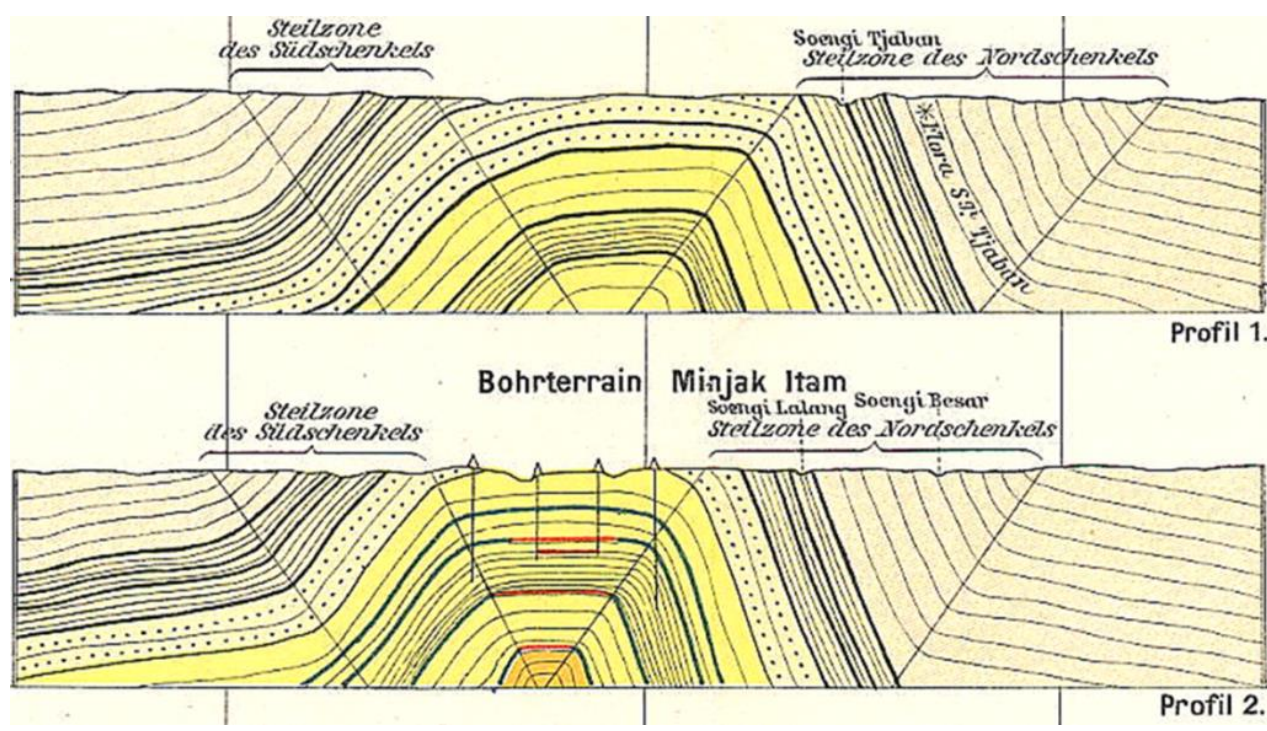

Figure 4: Profiles 1 and 2 of the Kampung Minyak - Minyak Hitam oil-field (Tobler, 1906). 


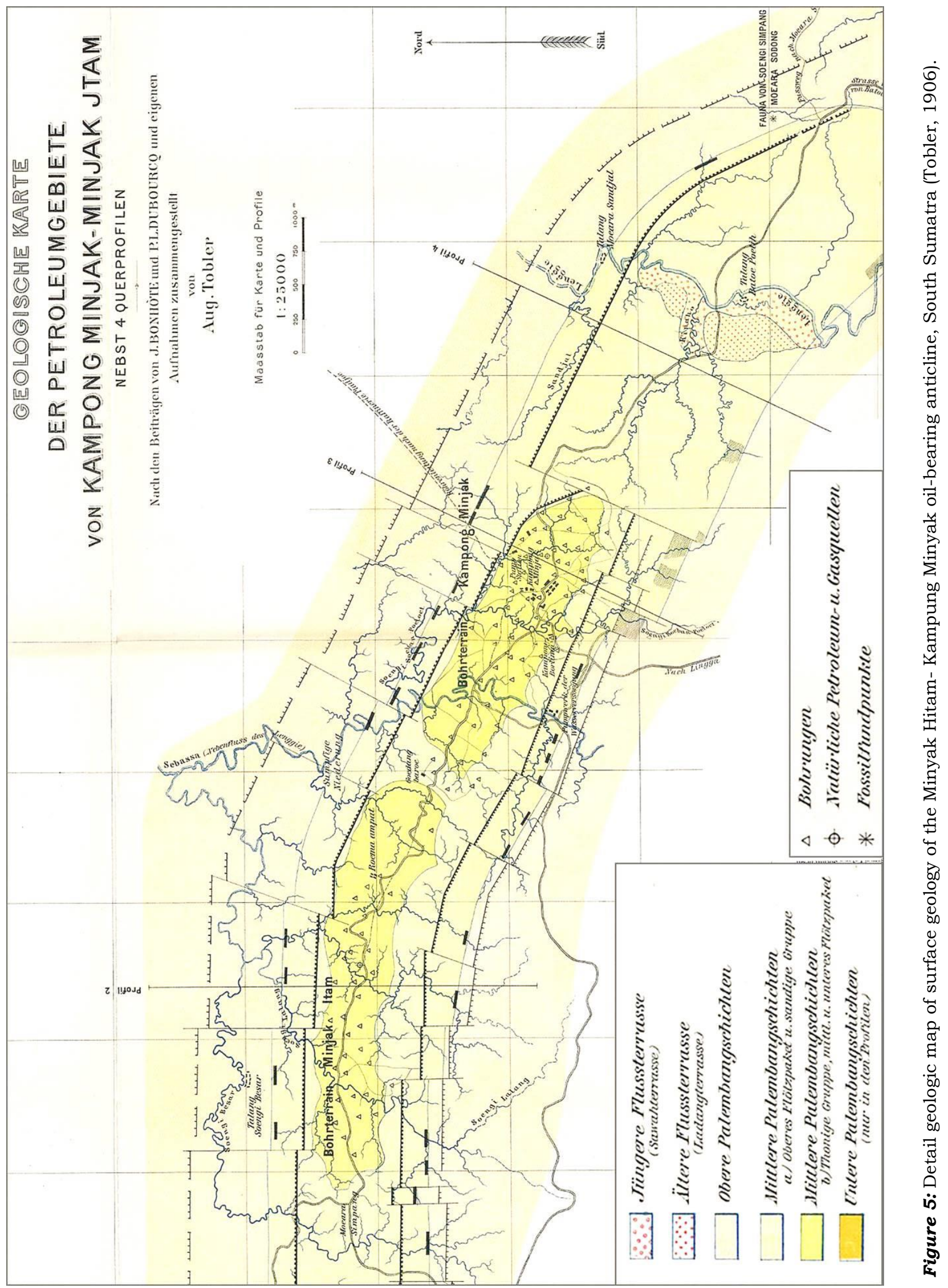



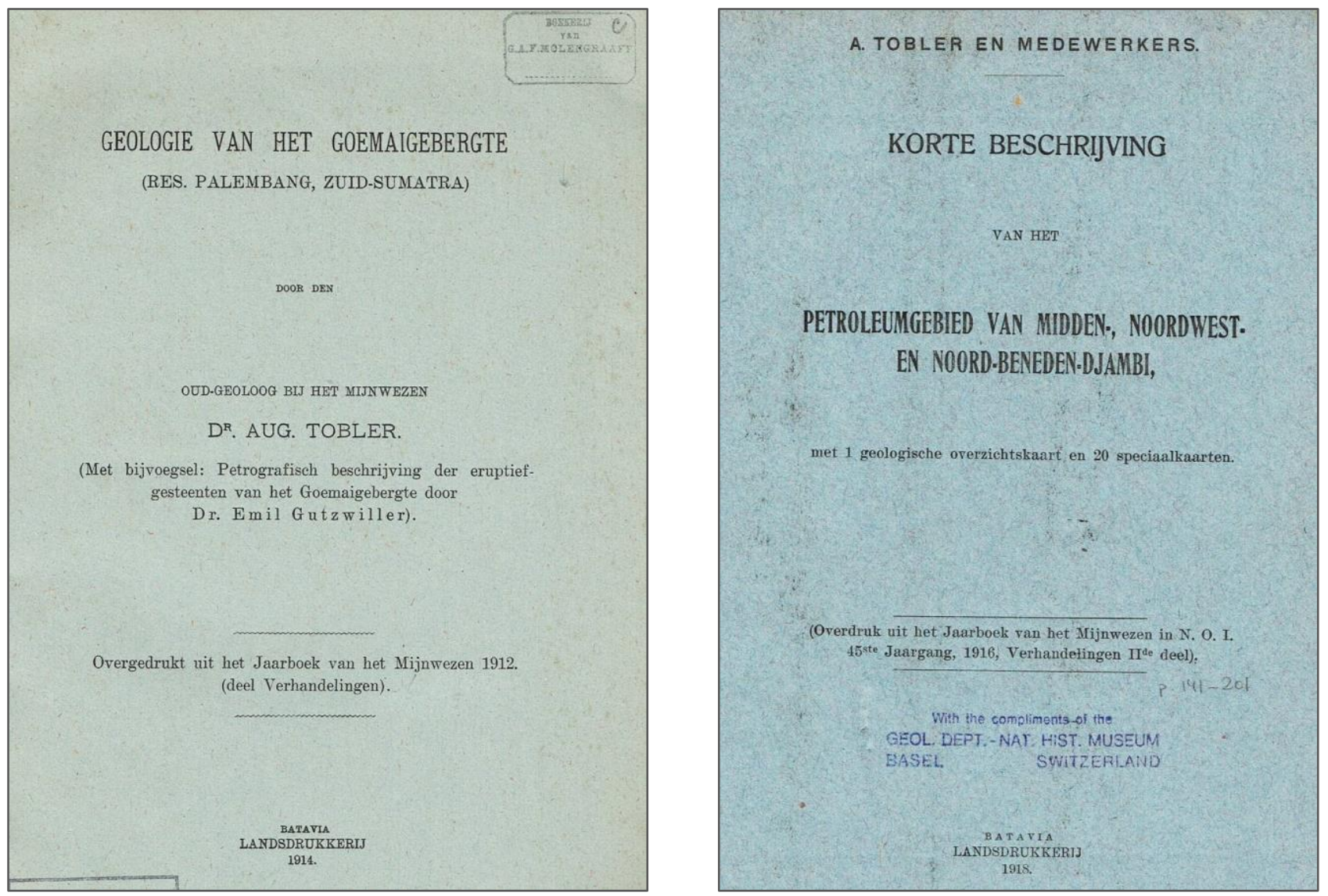

Figure 6: Left: Cover of the second of Tobler's South Sumatra geologic mapping reports, on the Jambi Basin (Tobler, 1918). Right: A 1914 paper on the geology of the Gumai Mountains in South Sumatra (Tobler, 1914).

sub-basin of the South Sumatra basin, in order to help evaluate its petroleum potential.

Among the Mijnwezen mining engineers and geologists that worked under Tobler's guidance on the Jambi petroleum geological mapping project for 1-3 years were Gollner, Oppenoorth, De Jongh, Douglas and others.

In addition to the mapping of the Tertiary sediments in the Jambi basin, Tobler also managed to include several forays into the poorly-known Barisan Mountains of the Jambi Residency, to study its Pre-Tertiary sediments, volcanics and igneous rocks, where he made some significant new discoveries. He demonstrated the presence of Permian-Cretaceous fossiliferous sediments, including the now-famous Permo-Carboniferous Jambi Flora in the upper reaches of the Merangin River. This led to the paleobotanic Djambi Expeditie of 1925, led by J. Zwierzycki and O. Posthumus, and much later to a Dutch-Indonesian expedition in 2004, both with the purpose of collecting Early Permian 'Cathaysian' plant fossils and understand their geologic setting.

Like Tobler's earlier South Sumatra projects, the results of the Djambi fieldwork were documented in unprecedented detail (Tobler 1912, 1913, 1918, 1922). The final Jambi report took almost 10 years to complete, and although it is 585 pages long and contains 20 maps, cross sections, etc., the title is only two words: Djambi Verslag (Jambi Report; Figure 9).

\section{Gumai Mountains, 1912}

Tobler's Jambi assignment with Mijnbouw ended in July 1912. After this, he spent several months pursuing areas of personal geological interest in Indonesia. One report claims he was in Sukabumi, West Java, for a few months, but most of the 
transition time was probably spent on fieldwork in the Gumai Mountains of South Sumatra (15 August - 10 October, 1912). Tobler found the geology of the Gumai Mountains to be quite different from how R.D.M. Verbeek had described it in 1883 (Tobler, 1914; Figure 7).
- in the East the Gumai Formation is thick ( 3000m), with thick basal sands (now called Talang Akar Formation) and no Baturaja Limestone.

This can now be understood as reflecting a NorthSouth trending pattern of Oligocene - Early

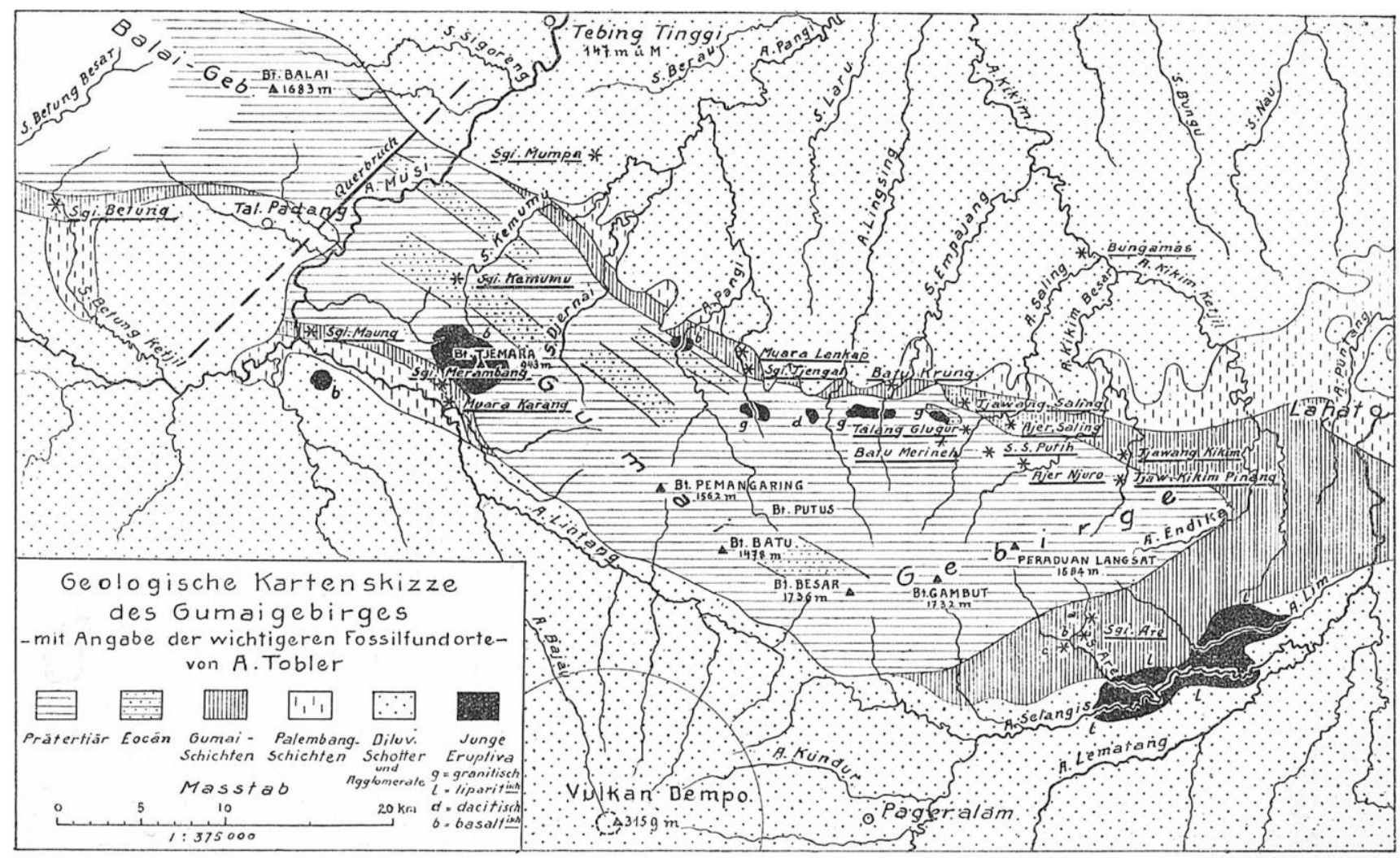

Figure 7: A 'geological sketch map' of the Gumai Mountains of South Sumatra by Tobler (1925).

Like the Garba Mountains, the Gumai Mountains are a post-Miocene anticlinorium, with a core of Mesozoic marine metasediments and limestones and 'diabase' volcanics, tuffs and granites, surrounded by Paleogene sandstones and Miocene Gumai shales and Palembang Formations.

An interesting observation from the Tobler mapping is the difference in thickness and facies of the Early Miocene sediments surrounding (overlying) the Gumai Mountains Pre-Tertiary core:

- in the West the Gumai Formation marine shales are thin $(\sim 300 \mathrm{~m})$, and are underlain by earliest Miocene Baturaja/Basal Telisa Limestone;
Miocene platformal and graben settings, cut obliquely by the younger NW-SE trending Gumai Mountains anticline.

\section{BARISAN MOUNTAINS PRE-TERTIARY ROCKS AND THE 'JAMBI NAPPES' THEORY}

In 1912 and 1917 Tobler proposed an alpine nappe-style tectonic model for the Pre-Tertiary of the Barisan Mountains of West Sumatra. In it, he interpreted a large nappe thrust sheet of relatively little deformed and non-metamorphic, Late Palaeozoic rocks of the Hoch-Barisan ('High Barisan) and the Vor-Barisan (Pre-Barisan; Permian volcanics and sediments), 

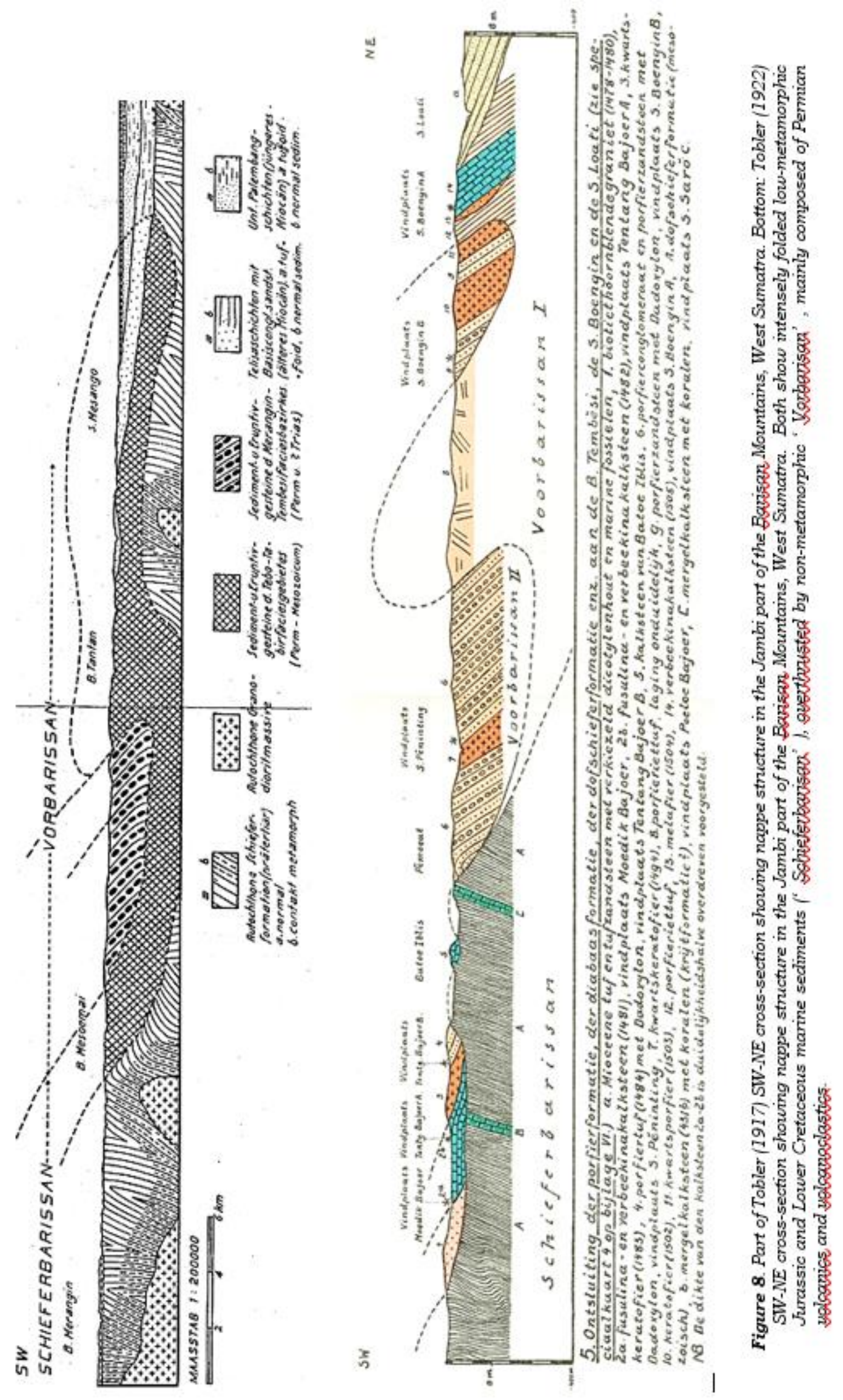

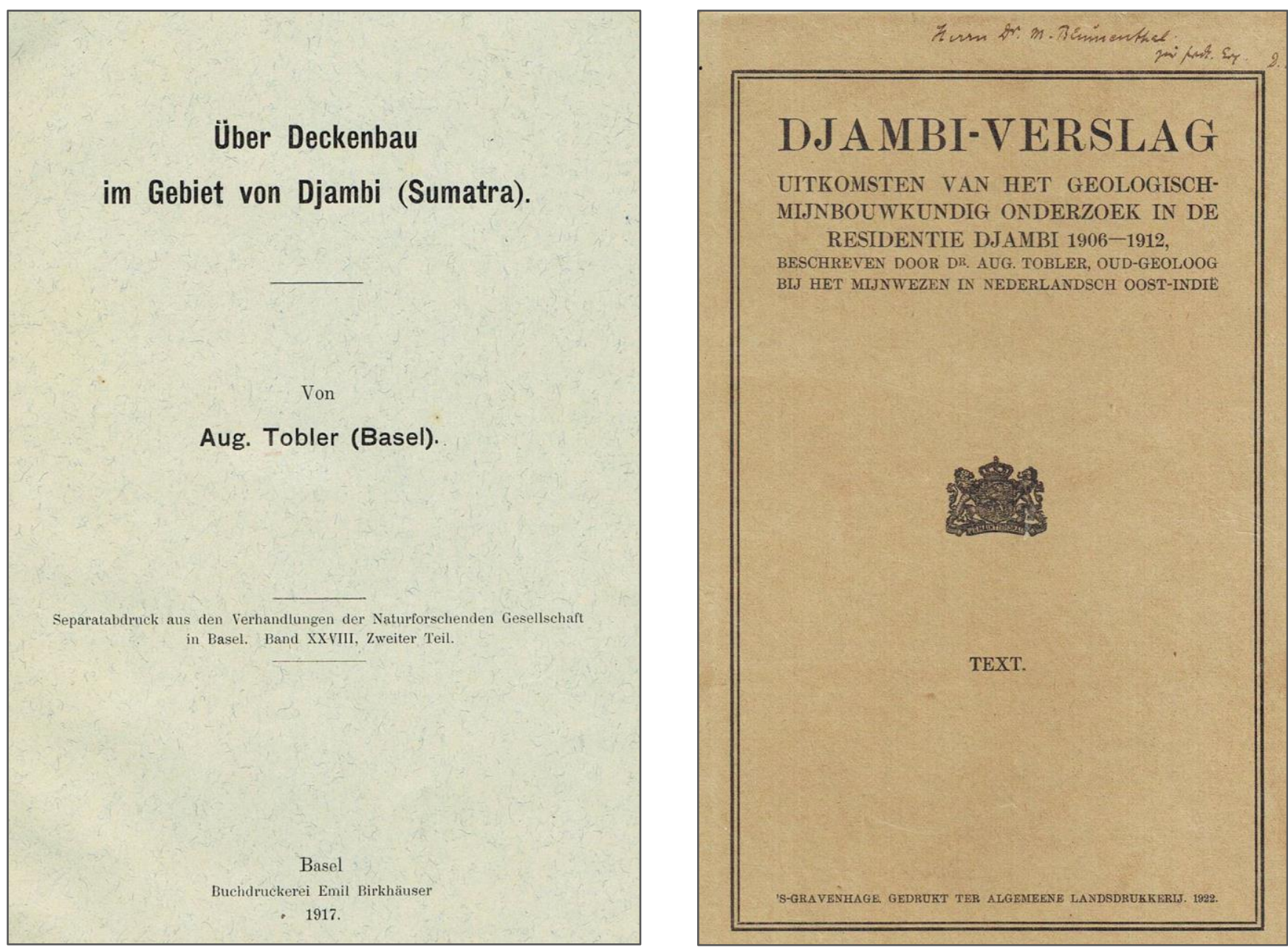

Figure 9: Left: Tobler's paper on his theory on nappe structures in the Jambi part of the Barisan Mountains, West Sumatra (Tobler, 1917). Right: Cover of the 'Jambi Report', the last of three major Tobler reports on Sumatra, documenting his geological surveys in the Jambi District between 1906-1912 (Tobler, 1922).

both of which were thrusted over isoclinally folded Lower Jurassic - Lower Cretaceous flysch-type metasediments of what he described as autochthonous Schiefer-Barisan ('shale/schist Barisan'; also known as Woyla terranes of later authors) (Figure 8).

This now 100-year-old overthrust model of Tobler was accepted by later workers active on Sumatra, like Zwierzycki (1930) and Van Bemmelen (1949) and Osberger (1955), but has been challenged by later authors (Klompe et al., 1957; Katili, 1970; Pulunggono and Cameron, 1984; and Barber and Crow, 2005). However, none of the skeptics spent as much time in the field as the experienced field geologists Tobler, Zwierzycki, Van Bemmelen and others did in the early 1900s. And, as noted by Tobler, field relationships between large tectonic units are hard to prove or disprove in Sumatra, where most of the older geology is covered by dense rainforest, Tertiary sedimentary basins and Quaternary volcanics.

\section{RETURN TO SWITZERLAND, 1912}

In late October 1912 Tobler returned by boat from Bengkulu, West Sumatra, to Batavia. In November 1912 he traveled from Batavia to Genoa, Italy, with the M.S. Rembrandt and from there to Basel, Switzerland, where he settled permanently. After a few more short consulting mapping projects during the first few years, Tobler was apparently 'financially secure' and spent the rest of his life as a private scientist in Basel, associated with the Natural History Museum, which was conveniently located across the street from his house. 


\section{A.K. Mas Bakal, Tobler's Indonesian Assistant}

From 1915 until his death in 1929, Tobler had a remarkable relationship with an Indonesian family with several young children, who for 15 years stayed in his house at Augustinergasse 5, across the street from the Naturhistorisches Museum in Basel. This was the family of Abdoel Koedir (or Kadir or Kuder) Mas Bakal, born in Kayu Agung near Palembang (date unknown), and Tobler's former field assistent and surveyor in Sumatra. Mas Bakal first came to Basel in 1913, to assist Tobler with fieldwork in Trinidad. In 1915 he returned to Basel with his wife and daughter, to work for 15 years as Tobler's personal assistant, until Tobler's unexpected death in 1929.

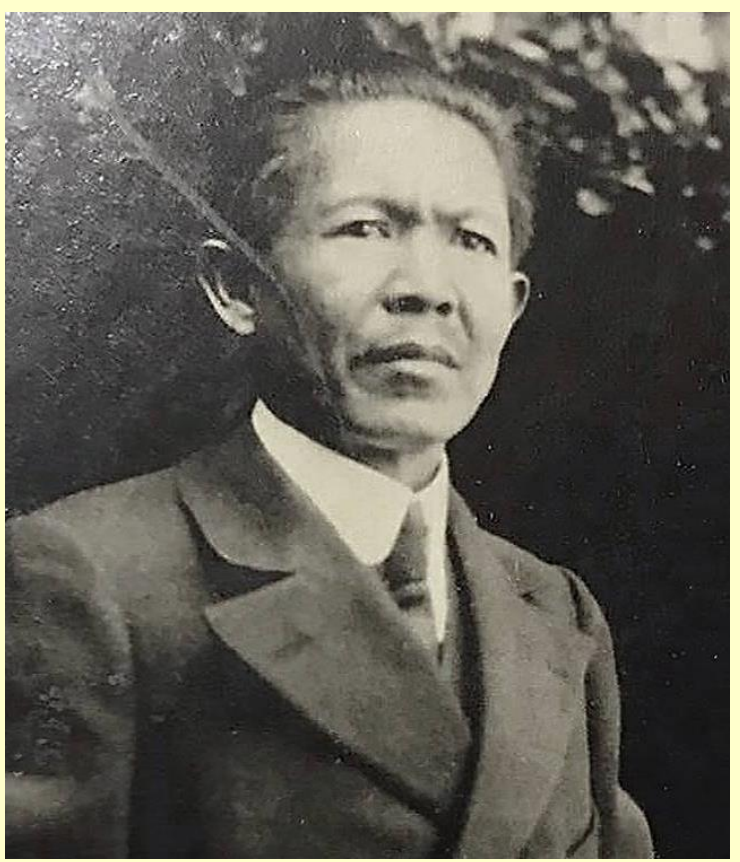

Mas Bakal assisted Tobler at the Basel Museum as museum technician, organizing the geological collections from the Netherlands Indies and work on samples. In the 1918-1930 City of Basel address books he was listed as Präparator.

Mas Bakal was also known for producing high-quality thin sections (Hottinger, 2013). I.M. van der Vlerk, in his 1922 thesis on larger foraminifera from Sumbawa, which was based on 500 limestone thin sections made by Mas Bakal, was very complimentary about the quality and quantity of his work.

After their fieldwork in Sumatra, Mas Bakal continued to accompany Tobler on all his geological fieldwork. The first overseas trip with Tobler and assistant $\mathrm{H}$. Kugler was six months of petroleum geological mapping fieldwork in Trinidad in 1913-1914. In the following years numerous field trips were made with Tobler in Switzerland and Germany.

Figure 10: A.K. Mas Bakal in the 1920s in Basel, Switzerland.

An interesting anecdote was that Mas Bakal (like many Indonesians in the past but not today) had difficulty pronouncing the letter $F$ and changed it to $P$ (Kugler, 1963). This may explain why his daughter, whose official name at birth was Fatimah, became Patimah later in life.

Tobler never married and viewed the Mas Bakal family, with wife Rakiah Dasarbatin and oldest daughter Mirjam, as part of his household. During their stay in Basel from 1916-1930 three more daughters were born: Saimah (1917), Fatimah (Patimah; 1917) and Bahilah (1928). Tobler looked after them and their education as if they were his own children (Stehlin, 1931) (Figure 11).

Tobler's unexpected death in late 1929 must have been a dramatic turning point for the Mas Bakal family. The Mas Bakal family with four children moved back to Indonesia in May 1930. Mas Bakal returned to Palembang and died there from a lung disease shortly afterwards.

The Mas Bakal daughters were highly gifted and spoke five or more languages. They went to some of the best schools and had successful careers. Oldest daughter Mirjam had already completed high school in Basel. She did not stay in Indonesia, but moved to Leiden, The Netherlands, in September 1930, to study for Pharmaceutical Assistant. She returned to Basel, Switzerland in 1932 and had 4 children and several grandchildren, who still live in Switzerland and Germany.

Two younger girls attended Catholic HBS high school in Batavia in the 1930s. Saimah trained to be a school teacher, then became a Catholic Ursuline nun and had several leading roles in the Catholic Church in Indonesia and The Philippines. Patimah went on to medical school in Batavia around 1940 and in the late 1940s at the University of Leiden, The Netherlands. She continued with a doctorate in 1960 and had a long career with the Department of Parasitology of the University of Leiden. Little is known about the life of Mas Bakal's youngest child Hussein, who was born in Palembang shortly after arrival back in Indonesia. 

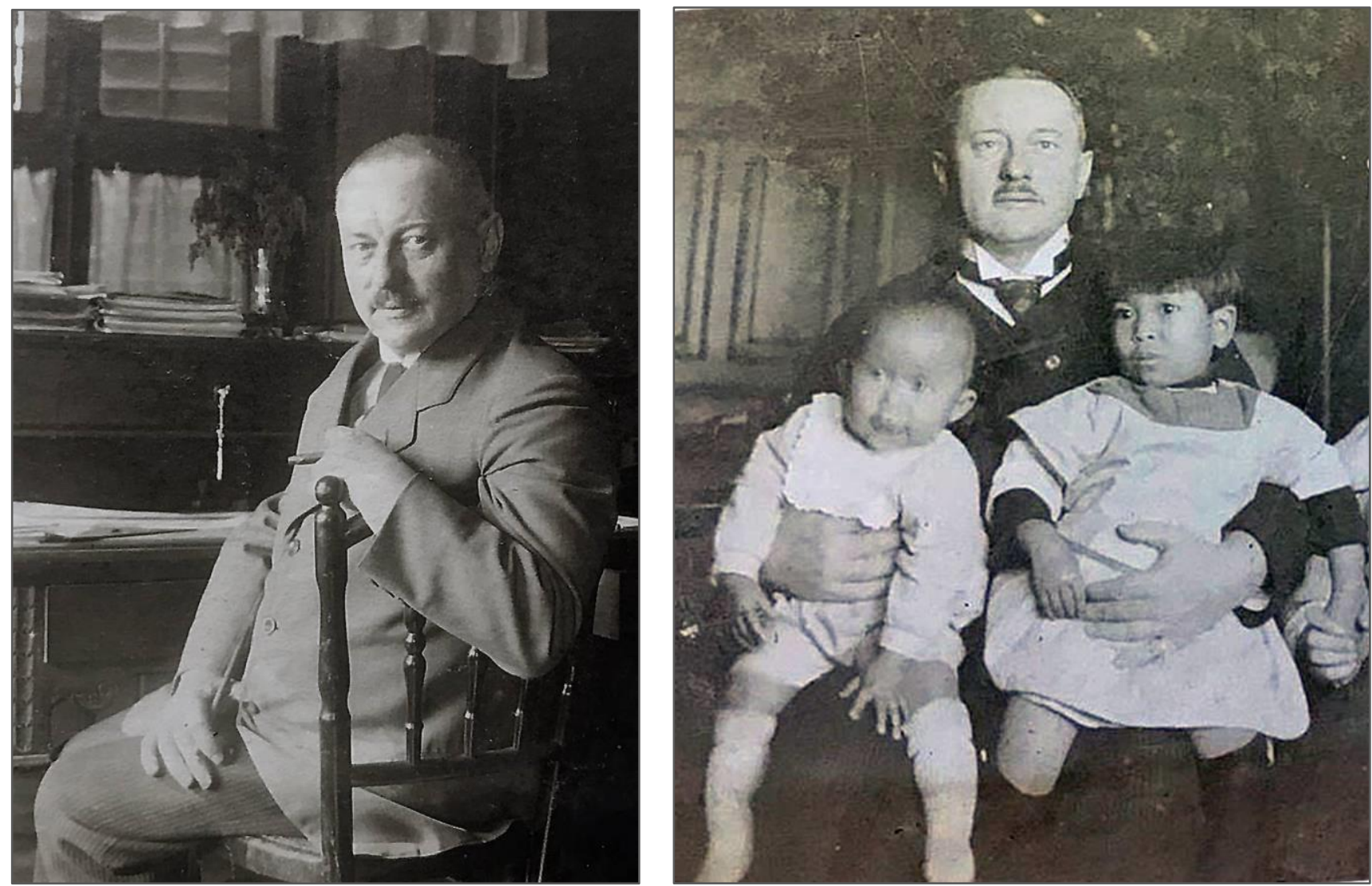

Figure 11: A. Tobler at home in Basel. On the right with his 'Indonesian family', the two oldest children of Mas Bakal, probably in 1918 (photos Mrs.Maja Redagne, Cologne, Germany)

Tobler had brought large collections of rock samples and ethnographic objects from Indonesia, which would form the core of the Indische Abteilung (Indonesia collections) of the Naturhistorisches Museum (Natural History Museum) and the Museum fur Völkerkunde (Ethnographic Museum; today named Museum der Kulturen) in Basel.

\section{Trinidad 1913-1914}

In November 1913 - July 1914 Tobler worked on a six-month geological mapping program in uncharted territory of SE Trinidad, on the concession of a new company Trinidad Leaseholds Ltd (TLL). Here Tobler brought several assistants. One was Tobler's former field assistant and surveyor from Sumatra, Abdul Kuder Mas Bakal (see below), the two others were student-assistants at the Basel museum, Hans G. Kugler and Fortunat Zyndel. Kugler later did his Ph.D. on the geology of an area in West Sumatra, based on
Tobler's notes and rock collections (Kugler, 1921). Through his later 1920s-1950s career H.G. Kugler became Chief Geologist of TLL and developed into the Father of Trinidad geology and micropaleontology.

All three had contracted malaria by Christmas during the Trinidad fieldwork, despite the fact that Tobler and Mas Bakal had assured young Kugler that eating sambal with dinner was an effective malaria prophylactic.

\section{'Gentleman scientist' in Basel, 1914-1929}

In July 1914 Tobler returned from Trinidad. The First World War now limited further overseas travels and Tobler spent much of his time until 1922 on finalizing reports on Trinidad and on the impressive final report of his Jambi, Sumatra, geological survey (Djambi-verslag; Tobler, 1922). These reports cemented Tobler's reputation as an 
expert in geological exploration and petroleum geology.

Apparently, Tobler had earned enough money from his $10+$ years of overseas fieldwork to retire from contract work or take up any other paid position. From 1918 until his death in 1929 Tobler worked at the Natural History Museum in Basel, as a private scholar and as volunteer curator of multiple geological collections, in particular those from the Netherlands Indies and North Borneo. The 'Indies collection' contained donations from Swiss geologists, mainly Tobler's Sumatra samples, but also from M. Mühlberg (BPM 1901-1911), A. Buxtorf, Fritz and Paul Sarasin, W. Hotz, G. Niethammer (NKPM) and J.J. Pannekoek van Rheden (Mijnwezen 1910-1914). The Indische Abteilung was merged into an Aussereuropäische Abteilung (outside Europe department) around 1920, and continued to be curated by A. Tobler and his Indonesian assistant Mas Bakal.

Tobler briefly lectured paleontology at the University of Basel and assembled a teaching collection of fossil invertebrates, which has been in use ever since (Hottinger, 2013). From 1920 to 1927 Tobler was Chief Editor of the prestigious Swiss geological journal Eclogae Geologicae Helvetica. In 1921 Tobler was one of the founders of the Schweizerische Paläontologische Gesellschaft (Swiss Paleontological Society) and was its President from 1926 to 1928.

\section{TOBLER THE PALEONTOLOGIST}

In addition to being a world-class geologist, Tobler also had diverse paleontological interests, especially later in life. Some of this was through his own studies, but he also 'jump-started' the paleontological careers of several students in Basel. In 1918 Tobler published his first paleontological paper, on Late Tertiary foraminifera-bearing limestones from Sumbawa.
The Tobler (1923) paper is a review of PaleozoicNeogene fossils, with a useful map of fossil localities of Sumatra. Tobler was the first to discover and collect plant fossils of the now famous Early Permian Jambi Flora of West Sumatra. These fossils would first be described by Jongmans and Gothan (1925), who named a new genus of primitive conifer-like seed pod fossils Tobleria.

Apparently, in his 1913 report on his field mapping in Trinidad, August Tobler was the first to visualize the potential value of foraminifera for the oil industry in Trinidad, and for worldwide correlations. Tobler was responsible for directing the early career of his assistant Richard E. Koch as the 'godfather of micropaleontology in RoyalDutch-Shell'. Under Tobler's supervision Koch worked on several pioneering studies on small benthic and planktonic foraminifera from Java, Borneo and Seram in 1922-1923, which led to a job setting up Shell's first micropaleontological laboratory in Venezuela and to Chief paleontologist for BPM-Shell in The Hague in the 1930s.

The idea was also picked up by another Tobler assistant, Hans G. Kugler, who established the first oil company micropaleontological laboratory in Trinidad, in Pointe-a-Pierre in 1929. Trinidad became a focal center in the development of Tertiary planktonic foraminifera biozonations in the 1950s, by pioneering micropaleontologists H.G. Kugler, H.M. Bolli, H.H. Renz, R.M. Stainforth and W. Blow.

Between 1918 and 1927 Tobler wrote a series of papers on Tertiary larger foraminifera, from Indonesia and other parts of the world (including two new species of Miogypsina from Sarawak in 1926). Tobler was also the teacher who supervised I.M. van der Vlerk, who did his doctorate at the University of Basel in 1919-1920, to become a leading authority on larger foraminifera from the Indonesian region between 1922 and 1974. Also 
Sonderabdruck aus dem Bericht über die dritte Jahresversammlu

der Schweizerisch logicr Helvetix, Band XV

Verlag von Emil Birkhäuser \& Cie., Basel.

Unsere paläontologische Kenntnis von Sumatra.

Von A. Tobler (Basel)

Mit einer Tafel (IX).

Buchdruckerei Emil Birkhäuser \& Cie

Basel.
Beiträge zur Geologie und Paläontologie von Sumatra.

UNTER MITWIRKUNG VON FACHGENOSSEN

HERAUSGEGEBEN VON AUG. TOBLER, BASEL.

$\mathrm{N}^{\circ} .11$.

Fossile Pflanzen aus dem Tertiär von Süd-Sumatra

voN

R. KRÄUSEL.

Overoedrukt Uit DE Verhandelingen van het Geologisch-

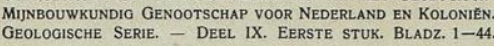

's-Gravenhage - N.V. Boek- en Kunstdrukkerij v/h. Mouton \& Co.

Figure 12: Left: Cover of the Tobler (1923) review of the paleontological knowledge of Sumatra. Right: A 1929 paper on Tertiary fossil plants of South Sumatra in the 'Beiträge zur Geologie und Paläontologie von Sumatra' series.

Manfred Reichel, the well-known Swiss specialist of the Alveolina group of larger foraminifera and founder of the 'Basel school of foraminifera', started his career in 1928, mentored by A. Tobler (L. Hottinger, 2013).

At Tobler's initiative 11 papers were published between 1921 and 1929 under the umbrella Beiträge zur Geologie und Paläontologie von Sumatra. These were papers mainly by paleontology experts that described fossils collected by Tobler in Sumatra, and include: Permian brachiopods (O.E. Meyer 1922, No. 2), Middle Jurassic bivalves (Frech and Meyer 1922, No. 3), Tertiary fossil woods (Krausel, 1922, No. 4), Permian fusulinid foraminifera from Guguk Bulat (Lange 1925, No. 5), Cretaceous fossils from Djambi (Baumberger 1925: No.6), Permian plant fossils (Jongmans and Gothan 1925; No. 7), Mesozoic foraminifera (Silvestri 1925, No. 9) and Tertiary plants South Sumatra (Krausel 1929; No. 11) (Figure 12).

\section{Academic theses in Basel}

Although Tobler did not have an official teaching position at the University of Basel, but several academic theses on Indonesian material were completed mainly under his supervision, including:

- G. Niethammer (1909), a petrographic study of igneous and volcanic rocks from the Loh Oelo high (Karangsambung) in Central Java. The samples were collected by Tobler in July 1902, during a break in his first South Sumatra 
fieldwork project, and were donated to the Naturhistorisches Museum in Basel.

- H.G. Kugler (1921), on the geology of the SangirBatanghari area in Sumatra, based on observations and samples collected by Tobler around July 1909. The rocks described were from all of the three Pretertiary tectonostratigraphic domains distinguished by Tobler in the Barisan Mountains: the Hochbarisan, Schieferbarisan and Vorbarisan.

- I.M. van der Vlerk (1922), future paleontologist with the Dienst van den Mijnbouw in Bandung, on Miocene larger foraminifera from Sumbawa, based on samples collected by government geologist J. Pannekoek van Rheden) (Figure 13).

\section{LEGACY}

Dr. A. Tobler was known as a quiet man, who never married. He passed away unexpectedly on 23 November 1929 , at the relatively young age of 57 , from a heart attack during a geological excursion to Jurassic outcrops in Huttingen, Germany. As usual when going to the field, Tobler was accompanied by his Indonesian assistant of 20 years, A.K. Mas Bakal.

The August Tobler-Stiftung (Foundation) was founded in March 1930, using money left by Tobler to fund the acquisition of mineralogical, geological and paleontological objects for the Natural History Museum in Basel and for the scientific processing of these collections.
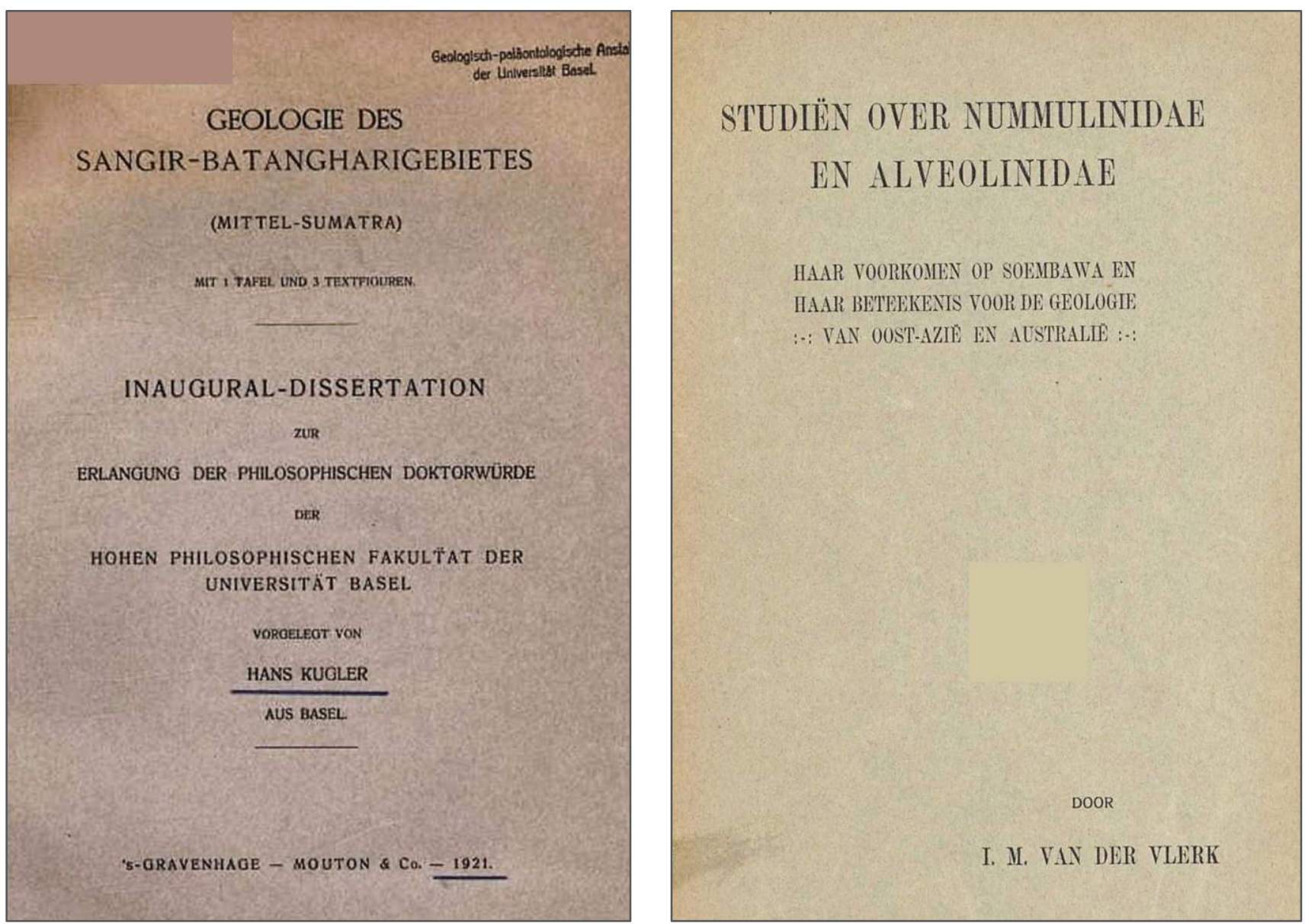

Figure 13: Two doctoral theses from the University of Basel on the geology of Indonesia and supervised by A. Tobler: Left: H. Kugler (1921) on the geology of an area in the Barisan Mountains in Central Sumatra, based on Tobler's material; Right: I.M. van der Vlerk (1922) on Miocene larger foraminifera from Sumbawa. 


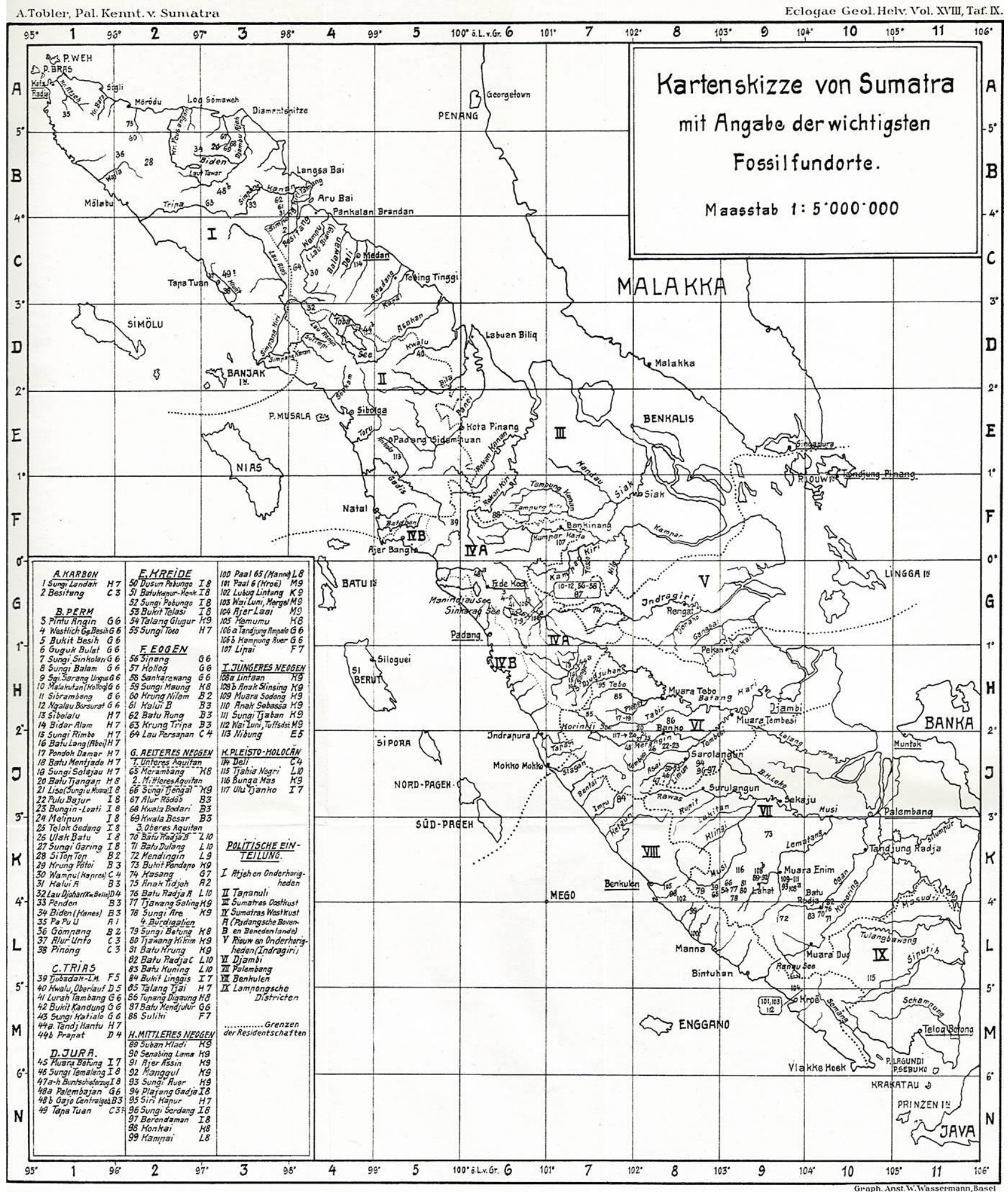

Figure 14: Map of Sumatra showing the 117 most important fossil localities, grouped by age (Carboniferous Pleistocene) (Tobler, 1923).

Tobler's scientific legacy includes many geologic maps and rock descriptions, which are known for detail and accuracy. In my personal experience of fieldwork in South and Central Sumatra, these maps and reports are still the most reliable available for certain areas. The Jambi reports of 1913, 1918 and 1922 are still unrivalled classics on the surface geology of the Tertiary Jambi subbasin of South Sumatra and the adjacent Pre- 
Tertiary rocks of the Barisan Range part of the Jambi Residency.

\section{ACKNOWLEDGEMENTS}

The authors like to acknowledge the historic photographs and information provided by Mrs. Maja Redagne, Cologne, Germany (granddaughter of A.K. Mas Bakal), and documents and information from Dr. Michael Knappertsbusch, Curator at the Natural History Museum in Basel.

\section{KEY PUBLICATIONS}

Tobler, A. (1904)- Einige Notizen zur Geologie von Südsumatra. Verhandlungen der Naturforschenden Gesellschaft Basel 15, 3, p. 272292.

Tobler, A. (1906)- Topographische und geologische Beschreibung der Petroleumgebiete bei Moeara Enim (Süd-Sumatra). Tijdschrift Kon. Nederlands Aardrijkskundig Genootschap (2) 23, 2, p. 199315.

Tobler, A. (1912)- Voorlopige mededeeling over de geologie der Residentie Djambi. Jaarboek Mijnwezen Nederlandsch Oost-Indie 39 (1910), Verhandelingen, p. 1-29.

Tobler, A. (1912)- Korte beschrijving der petroleumterreinen gelegen in het Zuidoostelijk deel der Residentie Djambi (Sumatra). Dienst van het Mijnwezen Nederlandsch-Indie, p. 1-29+20 maps

Tobler, A. (1913)- Korte beschrijving der petroleum terreinen gelegen in het zuidoostelijk deel der residentie Djambi (Sumatra). Jaarboek Mijnwezen Nederlandsch Oost-Indie $40 \quad$ (1911), Verhandelingen, p. 12-28.

Tobler, A. (1914)- Geologie van het Goemai gebergte (Res. Palembang, Zuid Sumatra). Jaarboek
Mijnwezen Nederlandsch Oost-Indie 41 (1912), Verhandelingen, p. 6-49.

Tobler, A. (1917)- Uber Deckenbau im Gebiet von Djambi. Verhandlungen der Naturforschenden Gesellschaft Basel 28, 2, p. 123-147.

Tobler, A. (1918)- Korte beschrijving van het petroleum gebied van Midden-, Noordwest en Noord-Beneden-Djambi. Jaarboek Mijnwezen Nederlandsch Oost-Indie $45 \quad$ (1916), Verhandelingen II, p. 141-201.

Tobler, A. (1918)- Notiz über einige foraminiferenfuhrende Gesteine von der Halbinsel Sanggar (Soembawa). Zeitschrift Vulkanologie 4, p. 189-192.

Tobler, A. (1921)- Beiträge zur Geologie und Paläontologie von Sumatra, unter Mitwirkung von Fachgenossen, 1-7. Mouton \& Co., 333p.

Tobler, A. (1922)- Djambi verslag. Uitkomsten van het geologisch-mijnbouwkundig onderzoek in de residentie Djambi 1906-1912. Jaarboek Mijnwezen Nederlandsch-Indie (1919), Verhandelingen III, p. 1-585 + Atlas of maps and cross-sections

Tobler, A. (1923)- Unsere palaeontologische Kenntniss von Sumatra. Eclogae Geol. Helvetiae 18, 2, p. 313-342.

Tobler, A. (1925)- Mesozoikum und Tertiär des Gumaigebirges. Verhandelingen GeologischMijnbouwkundig Genootschap Nederland Kolonien, Geol. Serie 8 (Verbeek volume), p. 521535.

Tobler, A. (1925)- Miogypsina im untersten Neogen von Trinidad und Borneo. Eclogae Geol. Helvetiae 19, p. 719-722.

Kugler, H. (1921)- Geologie des SangirBatangharigebietes (Mittel-Sumatra). Verhandelingen Geologisch-Mijnbouwkundig 
Genootschap Nederland Kolonien, Geol. Serie 5, 4, p. $135-201$.

Jongmans, W.J. \& W. Gothan (1925)- Beitrage zur Kenntnis der Flora des Oberkarbons von Sumatra. Verhandelingen Geologisch-Mijnbouwkundig Genootschap Nederland Kol., Geol. Serie 8 (Verbeek volume), p. 279-303.

Osberger, R. (1955)- Uber Deckenbau und andere geologische Probleme im Pratertiär Sumatras. Neues Jahrbuch Geol. Paläontologie, Monatshefte 1955, 8, p. 321-341.

\section{BIOGRAPHIC LITERATURE}

Kugler, H.G. (1930)- August Tobler, 1872-1929. Verhandlungen der Schweizerischen Naturforschenden Gesellschaft 111, p. 447-458.
Kugler, H.G. (1963)- Erste Erlebnisse eines Basler Petroleumgologen. Basler Stadtbuch 1963, 83, p. 109-147.

Oppenoorth, W.F.F. (1930)- Necrologie van Aug. Tobler. De Mijningenieur 11, p. 2-4.

Stehlin, H.G. (1931)- August Tobler 1872-1929. Verhandlungen der Naturforschenden Gesellschaft Basel 42, p. 177-195.

Hottinger, L. (2013)- Micropalaeontology in Basel (Switzerland) during the twentieth century:rise and fall of one of the smaller fields of the life sciences. In: A.J. Bowden et al. (eds.) Landmarks in foraminiferal micropalaeontology: history and development, The Micropalaeontological Society, Geol. Soc. London, Spec. Publ. 6, p. 317-335. 